\title{
DEMARCATING DEIFICATION AND THE INDWELLING OF THE HOLY SPIRIT IN REFORMED THEOLOGY
}

\author{
JOANNA LEIDENHAG* \\ University of St. Andrews
}

\begin{abstract}
The recent interest in exploring whether authoritative figures of the Reformed tradition employed a concept of theossis or deification in their soteriology continues to grow. However, it is yet unclear how the supposed implicit Reformed doctrine of deification relates to the more explicit concept of the indwelling of the Holy Spirit. Moreover, many of the arguments for theōsis in the theology of John Calvin, Jonathan Edwards, or T. F. Torrance seem to rely on confusing these two soteriological concepts. This makes it almost impossible to assess if it is theossis or the indwelling of the Holy Spirit (or some interesting combination) that is being appealed to in Reformed thinking. This paper makes a step towards unpicking the knot between the indwelling of the Holy Spirit and theōsis in Reformed theology by offering five possible ways to demarcate these two concepts. It is concluded that the final 'Mereological Demarcation' is currently the most acceptable.
\end{abstract}

KEYWORDS: deification, theōsis, indwelling, Holy Spirit, John Calvin, Jonathan Edwards

As has been noted by leading Reformed and analytic theologian, Oliver D Crisp, 'there is now a cottage industry devoted to showing how Protestant theologians of the past endorsed something like a doctrine of theōsis...' (Crisp 2012: 167). ${ }^{1}$ The ecumenical advantages of this work are clear, since theōsis, divinization, or deification (which as broad notions can be taken as synonymous within the Christian tradition, see Finlan and Kharlamov 2006) has often been considered as a distinctive element of Eastern Orthodox theology, whilst also being 'one of the oldest Christian symbols of salvation' (Kärkkäinen 2004: 8). To be precise, the 'cottage industry' as discussed in this paper is a debate concerning neither whether theōsis is true, nor compatible or logically consistent with Reformed theology, although both of these are implied. Instead, this is chiefly a historical and exegetical argu-

* JOANNA LEIDENHAG (PhD 2019, University of Edinburgh) is a Lecturer in Theology at the University of St. Andrews. Email: jmbl1@st-andrews.ac.uk.

1 I owe thanks to Oliver Crisp, Katrin Bosse, Joshua Cockayne, Oliver Langworthy, and other members of the Systematic Theology research seminar at the University of St Andrews for providing helpful comments on a previous version of this paper. 
ment examining whether the doctrine of theossis or theme of deification can be found within the writings of authoritative figures of the Reformed tradition.

Crisp defines theosis as "concerned both with the gradual transformation of the Christian by the indwelling of the Holy Spirit while she is a viator [a pre-mortem pilgrim]... as well as the connection between the phase of human life and postmortem existence in the presence of God' (Crisp 2012: 166). As we shall see, this definition and the strong emphasis it gives to the indwelling of the Holy Spirit already portrays a distinctly Reformed version of this doctrine, which has not yet been carefully worked out. One is left wondering how this definition of deification differs from sanctification or glorification, for example. The purpose of this paper is to inquire into the relationship between theosis and the indwelling of the Holy Spirit within Reformed theology, and to suggest some ways forward for demarcating these two soteriological concepts.

There seems to be three main positions in the debate over whether a doctrine of theōsis, or more broadly a concept of deification, can be found in authoritative figures within the Reformed tradition. Proponents of the first position, including Carl Mosser (2002, 2014, 2015), Joseph McClelland (1973), A. J. Ollerton (2011), Michael McClymond (2004), Stephen Holmes (2000: 58), William Danaher (2004), Kyle Strobel (2012b), Oliver Crisp (2020) and Myk Habets (2007, 2009), have all defended the thesis that Reformed theologians such as John Calvin, Jonathan Edwards and T. F. Torrance affirmed and employed a patristic doctrine of theosis, most frequently associated with Eastern Orthodoxy. The second position, argued for by Todd J. Billings (2005, 2007a, 2007b), Julie Canlis (2004, 2010), Gannon Murphy (2008) and Kyle Strobel (2016), states that although Reformed theologians affirm theosis, this constitutes a unique version of this doctrine to be demarcated from either patristic or Eastern Orthodox views in important ways. Although, F. W. Norris states that 'deification should be viewed... as an ecumenical consensus' (Norris 1996: 422), the father of Reformed theology appears to be an exception since, 'John Calvin seems to have avoided teaching deification or not known of it' (Norris 1996: 420). Norris' denial that Calvin employed the idea of theossis and that there is no distinctly Reformed contribution to the concept of deification constitutes the third position. In this third position, Norris is joined by the chorus of Bruce McCormack (2010), Robert Caldwell III (2006: 116-120), Jonathan Slater (2005), Sung W. Park (2017), Mark A. Garcia (2004), Marjin De Kroon (2001: 20), Charles Partee (2008: 175), D. Stephen Long (2010: 66), and François Wendel (1963: 235, 259)—all of whom deny that a doctrine of theōsis or conception of deification should be considered part of the Reformed theological tradition. 
It might be mentioned that while the difference between these positions is real, it is extremely easy to overstate. All these scholars agree that a Reformed soteriology includes some sort of union between Christ and believers, achieved through the 'wonderful exchange' of the incarnation and the indwelling of the Holy Spirit, and none claim that humanity partakes in the divine essence so that believers become equal with God by nature. It becomes difficult, then, to see precisely what is meant by deification in this debate. Myk Habets (2009) implies that 'justification', 'union', 'communion', 'adoption', 'glorification', 'worship', 'knowledge of God', and 'divinization' are all cognates of (or at least aspects of) theōsis (see also Mosser's expanded view of deification in, Mosser 2015: 9-10). As Hallonsten writes, 'Those themes, as might be expected, are to be found in nearly every Christian author throughout the ages, regardless of provenience... The problem, however, is that one ends up with a very general understanding of deification, which is not at all helpful...' (Hallonsten 2007: 282-83). It may well be that much of the dispute would resolve quite easily if an agreement on the minimal and maximal definitions of theossis was agreed upon first. This is, of course, easier said than done. Instead, a less ambitious goal may be to reach some agreement on how theōsis can be demarcated from parallel or overlapping soteriological concepts. To that end, this article considers the relationship between theossis and the indwelling of the Holy Spirit in Reformed theology.

The debate regarding the possibility of a reformed doctrine of theossis has resulted in a more precise discussion on Christology, in particular on the Reformers' view on the communication of properties between the divine and human nature of Christ (i.e., Sung 2017; Lee 2010). However, this debate has not yet led to a more precise discussion of Reformed teaching on the indwelling of the Holy Spirit. This oversight, concerning the role of the Holy Spirit in contemporary debates surrounding theosis, is surprising given the explicit importance of the Holy Spirit for achieving union with Christ, and thus for believers to receive the benefits of Christ's deified human nature in Reformed theology. Not only is the issue of theosis a useful platform from which to launch a more nuanced discussion of the indwelling of the Holy Spirit within Reformed theology, but we are unlikely to make progress in the debate regarding the possibility or prevalence of a Reformed doctrine of theosis, without giving fuller consideration to the role of the Holy Spirit.

The next section of this paper explores further what is at stake in demarcating theosis from the indwelling of the Spirit. Following this, the remainder of this paper evaluates five potential ways to demarcate theosis and the indwelling of the Spirit, ordered from those with the least potential to those with the greatest. Each is evaluated through engagement with how 
these concepts have been used in contemporary discussions and how they feature in the work of thinkers such as John Calvin or Jonathan Edwards. I conclude that the final Mereological Demarcation is the most promising way to relate these two concepts in Reformed theology. However, which model of demarcation is preferred is relatively unimportant in comparison to first agreeing that a demarcation is required. Scholars may wish to employ one of the suggestions I put forward, or indeed a demarcation of their own making. My main concern is to argue that such a demarcation is needed if we are to have a clearer understanding of our historical forebears, host nuanced ecumenical dialogues, and give fuller accounts of the assurance which we have and the hope to which we are called in Jesus Christ.

\section{Theōsis and/or Indwelling: What Is at Stake}

It is worth pausing to consider what is at stake in this search for a demarcation. After all, many contemporary scholars seem content to use the concepts of theōsis and indwelling somewhat interchangeably. However, this creates a substantial vulnerability in the argument that theosis is present within the Reformed tradition. One could argue that the 'cottage industry's' central argument-that theōsis is found within the Reformed theological tradition-relies upon the current lack of demarcation between these two concepts. The argument would follow that whenever contemporary commentators claim to see theosis being employed in the Reformers writings, all that is really going on in the text is an appeal to the indwelling of the Holy Spirit. Thus, the central exegetical and historical argument rests upon a mistake. I take this to be the most challenging defeater for the thesis that Reformed theology historically includes the concept of deification, although I have not seen this defeater be employed explicitly. The reason this defeater is powerful is because it seeks to undermine this thesis from within Reformed theology, rather than by attributing a definition of theōsis from without.

This defeater is the implication in Gösta Hallonsten's comment that the result of the overly vague and generalized way that the concept of theosis is being employed in contemporary scholarship means that, 'one might wonder if participation [theosis] and indwelling necessarily function as alternative[s] in [the] Christian tradition' (Hallonsten 2007: 289, n.14). The idea that indwelling and theōsis may function as alternatives, highlights how this doctrinal ambiguity leaves the arguments for a Reformed employment of theōsis vulnerable to the critique that attributing theōsis to Reformed theologians is a kind of category error. Even the possibility of such a severe criticism should be enough for proponents of a Reformed retrieval of theosis to consider this essays' search for a demarcation between theōsis and indwelling to be urgent. 
To be clear, I think that the critical argument outlined above is reliant upon a question begging dichotomy between indwelling and theosis; there is no a priori reason to believe that theossis and indwelling might not both be important aspects of an overarching soteriology. However, this only increases the need for a discussion around demarcation and a clearer understanding of how these two concepts may relate within soteriology. For example, in his argument for theōsis in Jonathan Edwards, William Danaher Jr. defines theosis as "whereby the love of God that is the Holy Spirit "indwells" in the saints' (Danaher 2004: 42). Danaher also states that, on the one hand, theossis occurs through the indwelling of the Spirit (Danaher 2004: 6) and, on the other hand, that the indwelling of the Spirit occurs 'through theosis' (Danaher 2004: 7). It seems that the two concepts are synonymous, such that one or other becomes superfluous. It is due to the lack of clear demarcation between different soteriological concepts that Norman Russell can, despite the large amount of in-depth studies affirming a Western theōsis, still confidently write, 'Whether you can really graft theōsis on to a Western theological approach remains to be seen' (Russell 2012: 15). Put bluntly, if we are not clear on how the (often unacknowledged) concept of theossis functions differently to, but alongside, more explicitly cited soteriological doctrines then it is almost impossible to be sure that theosis really is (or is not) present in the Reformers' thinking and writing.

A clear example of this problem is seen in the case of the prominent Scottish Reformed theologian, T. F. Torrance (1913-2007). Contemporary scholar Myk Habets has published a monograph defending the thesis that 'although the formal language of theosis may appear rather infrequently in Torrance's work, its material content is pervasive' (Habets 2009: 193). Habets takes as an exemplary quote from Torrance on theōsis to be:

Let us not quarrel about the word theōsis, offensive though it may be to us, but follow its intention... Theosis is an attempt to express the staggering significance of Pentecost as the coming from on high, from outside of us and beyond us, of divine power, or rather as the coming of Almighty God, the Maker of heaven and earth, to dwell with sinful mortal man, and therefore as the emancipation of man from imprisonment in himself and the lifting him up to partake of the living presence and saving acts of God the Creator and Redeemer (Torrance 1975: 234-44; Habets 2009: 1).

In this quote, Torrance explicitly frames theōsis as a doctrine concerning Pentecost and the redemptive effects of the indwelling of the Holy Spirit. Moreover, Torrance argues that this is not merely his own interpretation of this term, but that when referring to theosis the patristic theologians only ever really had in mind the indwelling of the Holy Spirit. Torrance writes, 
According to the real intent of what the Nicene theologians called theosis or theopoiesis is not, technically speaking, the 'deification' or 'divinisation' of humanity, but the immediate presence of the Holy Spirit through whom we participate in the revealing and saving activity of God in the vicarious humanity of Jesus Christ (Torrance 1989: 112-13; Habets 2009: 162).

Theossis for Torrance is not merely achieved by virtue of the indwelling of the Holy Spirit, but is simply another way of referring to the indwelling of the Holy Spirit (see also Torrance 1965: 217; Torrance 1975: 214). In fact, the only time Torrance affirms theosis is when he simultaneously reinterprets its meaning into the indwelling of the Holy Spirit.

What are we to make of Habets's thesis, when Torrance only uses the term theosis when it is explicitly qualified to refer to the indwelling of the Spirit? Based on this very brief evidence, it already seems likely that Torrance's references to theōsis are nothing more than ecumenical gestures and, do not, as Habets suggests, provide a window into a deeper employment of theossis in Torrance's theology. I am not, in fact, trying to argue that Habets is mistaken.

My point is only to show that without a clearer understanding of how the concepts of theossis and indwelling relate to one another, it is hard to be convinced that Reformed theologians are using one, and not the other, of these concepts. Alternatively, it may be that contemporary scholars come to the consensus that theosis and the indwelling of the Holy Spirit really are entirely synonymous concepts, such that to reinterpret one doctrine in the terminology of the other (as Torrance does) leaves no theological remainder. In that case, the overlap between indwelling and theosis needs to be argued for more fully, and the discussion around the Reformers' use of theosis needs to be adjusted accordingly.

However, it is my wager that theossis and the indwelling of the Holy Spirit really do refer to different soteriological phenomena and concepts across the broad Christian tradition, and thus need to be properly demarcated. It should be noted that a call for demarcation is not the same as an opposition, and a distinction is not to be equated with separation. All doctrine, in so far as they are valid, will be related to, overlapping with, other doctrine. As will be seen below this paper is as concerned with how to relate indwelling and theōsis as it is with how to demarcate indwelling and theossis. 


\section{Moving the Conversation Forward: Possible Demarcations between Indwelling and Theōsis}

In the following section, I will evaluate five possible ways of demarcating theossis and the indwelling of the Holy Spirit within the Reformed tradition. ${ }^{2}$ The testing out of these demarcations also provides this paper the opportunity to delve deeper into the use of these concepts in key thinkers such as Jonathan Edwards and John Calvin. It is concluded that the final model, which I call the Mereological Demarcation, is the most satisfactory in accounting for a wide range of theological data, including the continuing controversy and lack of clarity in contemporary uses of terms like theossis, deification and divinization.

\section{Demarcation 1: Orthodoxy and Heterodoxy}

A demarcation between the indwelling of the Holy Spirit and theosis on the grounds that the former is an orthodox doctrine, whereas the latter is heterodox is a highly question-begging and largely unhelpful assertion. Widespread amongst proponents of the third position (see above), this demarcation is often stated without further argumentation or definition and so reveals nothing but theological prejudice. (For a compelling narrative explaining the historical and political reasons for this prejudice, see Mosser 2014: 40-44; Mosser 2015: 11-13.) Where argumentation is given, it is most often suggested that theōsis is heterodox because, as with ancient polytheisms and Hellenistic mythologies, it places God on a scale with creation thereby violating the absoluteness of the Creator-creature distinction. If this

2 There are two further demarcations I have considered but not included here for the sake of space. First, is a demarcation based on the way actions are attributed to God. The indwelling of the Holy Spirit is a type of divine-human relationship and divine action that the tradition has seen fit to attribute especially to the Holy Spirit. Theōsis or deification is frequently spoken of as an action of the whole Trinity, or as human participation in the Triune life. The argument that indwelling and theosis can be demarcated on the basis that one refers solely to the actions of the Holy Spirit and the other to the actions of the whole Trinity, however, is a false one. This is because the willing and acting of God is indivisible so that no one person of the Trinity can act without the other two. Whatever one person of the Trinity is said to do, the others do also. All actions of the Trinity are commonly said to be 'from the Father, through the Son and in the Holy Spirit', even though based on revelation and tradition we commonly attribute an action, say indwelling, to one person of the Trinity, say the Holy Spirit. Second, is a demarcation based on a distinction between individual and communal forms of salvific activity. One might suggest that whereas the indwelling of the Holy Spirit is a relationship God has with an individual, theossis only occurs communally to the whole people of God. However, the centrality of the indwelling of the Holy Spirit to the creation of the Church (as seen in Pentecost) and the importance of retaining personal identity within theōsis, make pressing this distinction a fraught exercise. It seems to me that as social and relational creatures, all aspects of human salvation are simultaneously communal and individual, and it does not serve theology well to divide them up in this manner. 
is the case then the fear is that humanity may be said to be divine by nature, rather than by grace and grace alone. Clearly, if this is what is entailed by the doctrine of theossis then it would be anathema to Reformed theology (and to other Christian traditions). However, this is not what is being argued for by contemporary proponents of the thesis that Reformed theology contains either an ecumenical or distinctly Reformed notion of theōsis.

It is worth lingering on this failed means of demarcation a little longer for it further reveals the fundamental problem that this paper seeks to highlight. It seems to me that Reformed theologians frequently employ the language of the indwelling of the Holy Spirit precisely to avoid any heterodox implications of deification as uniting with the divine essence by nature. We might take the theology of Jonathan Edwards as an example here.

Kyle Strobel and James Salladin both argue that Edwards consistently employs a distinction between the incommunicable divine essence and the communicable divine nature or fullness (Strobel 2016; Salladin 2017). The divine nature or fullness refers to God's life ad intra whereby the Son is the self-understanding of the Father and the Spirit is the will and self-love shared between the Father and the Son (Strobel 2016: 376; 2012a: 23-72; cf. Crisp 2014; Holmes 2001: 69-71). It is by receiving the Spirit, who is the self-love of the Father and the Son, that believers can participate in the Triune life; just as the persons of the Trinity participate in one another ad intra in addition to their shared essence, and just as the human Jesus is united to the Logos by the Spirit (Caldwell 2006). This cascade of participation comes in differences of degree, but not in kind, since each is achieved by the gift of the Holy Spirit (Salladin 2017: 437-38).

This pneumatologically laden distinction between essence and nature/fullness allows Edwards to make some very strong claims regarding the believers deification, such as: '[T]he saints are said to be "partakers of God's holiness", not only as they partake of holiness that God gives, but partake of that holiness by which he himself is holy' (Edwards 1994: 513). We are told elsewhere that this holiness is 'the proper nature of the Holy Spirit' (Edwards 1989: 639; Strobel 2016: 377-378). And,

the Spirit of God in the souls of his saints exerts its own proper nature; that is to say, it communicates and exerts itself in the soul in those acts which are its proper natural and essential acts in itself ad intra, or within the Deity from all eternity (Edwards 1994: 513-14).

Edwards even suggests that the indwelling of the Spirit allows the transformed human soul to 'admit divine light' (Edwards 1959: 343; 1994: 46263). Finally, Edwards writes that indwelling allows the believer to be 'as it were swallowed up in him [the Spirit]: so that his respect to them finally 
coincides and becomes one and the same with respect to himself' (Edwards 1989: 443). ${ }^{3}$

Jonathan Edwards' depiction of the indwelling of the Holy Spirit seems close, not only to a general or broad notion of deification, but to the more radically Palamite doctrine of theōsis (McClymond 2004: 144-50; Holmes 2000: 58; Danaher 2004: 42). The strength of Edwards' deification language, without the employment of the more recognizable Palamite distinction between essence and energies, has left some readers wondering if Edwards' did in fact collapse the Creator-creature distinction. This is something Edwards adamantly denied, and he did so again by recourse to the Spirit as the communicable form of the divine nature and fullness. Consider the following quote,

Not that the saints are made partakers of the essence of God, and so are 'Godded' with God, and 'Christed' with God, according to the abominable and blasphemous language and notions of some heretics: but to use the Scripture phrase, they are made partakers of God's fullness... And the influences of the Spirit of God in this, being thus peculiar to God, and being those wherein God does, in so high a manner, communicate himself, and make the creature partaker of the divine nature (the Spirit of God communicating itself in its own divine nature) (Edwards 1959: 203. Italics added).

Edwards here enforces a demarcation between the indwelling of the Holy Spirit as the partaking in the divine nature and fullness from the notion of divinization as being 'Godded', or partaking in the divine essence. However, there is no demarcation between the indwelling of the Holy Spirit and an acceptable notion of theossis. To the contrary, identifying indwelling with deification is the basis for Edward's affirmation of this controversial doctrine. Is Edwards' then affirming anything other or more than the indwelling of the Holy Spirit in these passages, such that we might refer to this extra union as theosis? If we have no demarcation between these two concepts, then we simply cannot answer this question decisively. The potential confusion between these doctrines becomes more urgent given that relating the indwell-

3 If one accepts that Edwards employed a dispositional metaphysics, as Sang Hyun Lee has argued, then this language becomes even stronger, such that it becomes very difficult to defend Edwards against the critique that he adopts the kind of heretical view of theōsis (as humanity become gods in their nature) that Edwards himself denies. This is because if reality is dispositional (made up of habits, laws, and dispositions, rather than substances), and the infusion of grace by the Holy Spirit give human beings divine dis positions, or the Holy Spirit becomes the 'principle of life and action' in the believer, then this amounts to transforming human nature into a divine nature without remainder. This is perhaps one more reason not to interpret Edwards as positing a dispositional metaphysics. See Holmes 2003; Crisp 2010. 
ing of the Holy Spirit to theōsis seems necessary in order to avoid more heretical notions of theosis that are consistently denied in Reformed theology.

\section{Demarcation 2: The Direction of Participation}

In her analysis of theossis in Thomas Aquinas and Gregory of Palamas, A. N. Williams writes:

Yet there is a firm core that distinguishes this doctrine [theōsis] from some other model of sanctification. First, we can safely say that where we find references to human participation in the divine life, there we assuredly have a claim specifically of theōsis. This kind of claim regarding participation in the divine life is carefully to be distinguished, however, from the idea of divine indwelling in the human person... A second infallible marker of the doctrine, then, is the union of God and humanity, when this union is conceived as humanity's incorporation into God, rather than God's into humanity, and when conceived as the destiny of humanity generally rather than the extraordinary experience of the few... (Williams 1999: 32 Italics added).

Despite allowing theossis to be a fairly expansive concept (any notion of human participation in the divine life), Williams still states the need for a demarcation between theōsis and God's indwelling in believers. For Williams, the language of participation in these two doctrines moves in opposing directions. To put it simply, in theōsis we participate in God, in the indwelling of the Holy Spirit God participates in us. If anything meaningful is being suggested by these metaphors of directionality and language of participation, then it seems that theosis and indwelling are not identical concepts.

However, a demarcation of immaterial (or at least supra-material) relations based upon the location or the direction of participation seems somewhat ambiguous without further development. What difference does it make to the transformation of humanity if we are in God or God is in us? Perhaps, 'we are in God' is a grace-based model implying human passivity, whereas 'God in us' suggests a more synergistic mode of transformation through divine aid and human effort? It is not clear. One could easily reverse this interpretation or suppose an entirely different kind of distinction. This demarcation could perhaps prove helpful, but further discussion regarding the directionality of the divine economy and the meaning of 'in' in this context is needed. ${ }^{4}$ The risk, then, is that to solely demarcate theosis and indwelling through this semantic terminology is again to create a distinction without a meaningful difference. 


\section{Demarcation 3: The Scope of the Recipients}

In the quote above, Williams offers a second form of demarcation. She claims that theōsis is the telos of all humanity (contrary to the Palamite concept of theosis which is achieved through the elite practice of Hesychasm) and the indwelling of the Holy Spirit is reserved as 'the extraordinary experience of the few' (Williams 1999: 32). Williams' suggestion that only a few receive the Spirit, like some Pentecostal ideas of spirit-baptism, is a controversial and a problematic doctrine. Yet, Williams' suggestion that the difference between theosis and the indwelling of the Holy Spirit may regard the inclusivity or the scope of these two doctrines seems promising. Scope is one of the main ways that Andrew Louth differentiates between Eastern and Western views on redemption. Louth argues that the Eastern Orthodox notion of theosis is distinctive from other teachings on redemption in the Christian tradition due to its cosmic scope. Louth writes,

[D] eification is not to be equated with redemption. Christ certainly came to save us, and in our response to his saving action and word we are redeemed; but deification belongs to a broader conception of the divine ókovouia: deification is the fulfilment of creation, not just the rectification of the Fall... it is, I think, not unfair to suggest that such a concentration on the lesser arch [of Fall to redemption] at the expense of the greater arch [of creation to deification] has been characteristic of much Western theology (Louth 2007: 34-35).

According to Louth, there is an expectation in Orthodox theology, largely absent from Western doctrine, that all of creation will be deified, or taken up into the divine life. In so far as the contemporary retrieval of Reformed accounts of theosis has focused solely on the deification of human beings, then Louth appears justified in citing the cosmic scope of his own Eastern Orthodox doctrine of theōsis as distinctive from its Western counterpart. This could be a result of the close connection in Reformed theology between deification and the indwelling of the Holy Spirit, which is perceived as a gift given to human beings, received in (some kind of) connection with baptism. If this is the case, then it would seem that the overlap between the indwelling of the Spirit with the notion of deification within Reformed theology functions in such a way as to draw it apart from Orthodox teaching, giving credence to Hallonsten's thought that indwelling and theossis may function as alternatives rather than synonyms. Niesel makes this argument when he denies that deification is appropriate language for Calvin because Calvin's understanding of the unio mystica with Christ is not between created being and Divine being but between the sinner and the Redeemer. It is not a doctrine of being (ontology) but a doctrine of salvation (soteriology)' (Niesel 1962: 184-5). 
However, Norman Russell's analysis of theossis suggests that Louth is not speaking for the breadth of the Orthodox tradition here. Russell distinguishes between two types of theossis in patristic and modern Orthodox thought. The first 'takes its cue from the cosmic theology and philosophical pattern of St. Maximus and the later Fathers' and representatives include Sergius Bulagkov, Vladimir Lossky, and Andrew Louth. The second type, however, 'returns to the more biblical focus of Athanasius and Cyril' and is 'focused more intensely on the incarnate son'. Modern representatives of this second type include Panayiotis Nellas, John Zizioulas, and John Behr (Keating 2015: 279; Russell 2004; see the same distinction in Williams 1983: 106). It is this second type that the revivalists of a Reformed doctrine of theology seem most in line with. The question of scope is, then, a meaningful demarcation, but not between indwelling and theosis within Reformed theology. Instead, scope functions, at most, as a way of demarcating differing types of theōsis.

\section{Demarcation 4: Epistemology and Ontology}

The final two attempts at demarcation also explore differences of scope. First, in terms of the scope of transformation in the human person and, second, in terms of the scope of God's total saving action. Both investigations are tested in reference to John Calvin's theology, which is at the forefront of the recent debates concerning a Reformed doctrine of theossis.

It may be that the indwelling of the Holy Spirit refers to an epistemological union with God and transformation of the human person, whereas theōsis refers to an ontological union with God thereby implying a more encompassing transformation of the human person. Calvin is well-known for emphasizing the Holy Spirit's role as an 'inner teacher', whose 'principle work' is to grant faith and enlighten truth in the mind of the believer (Calvin 1960: 541). One might employ Calvin's commentary on 2 Peter 1:3-4 to exemplify this mode of demarcation between theosis and the indwelling of the Holy Spirit. 2 Peter 1:4 is often cited as the biblical proof text for theosis, and it is in reference to this passage that Calvin describes God's promises to 'make us partakers of the divine nature, than which nothing can be conceived better' (Calvin 1963: 330). By contrast, in the prior verse, Calvin emphasizes the Spirit's work in voicing the irresistible inner call to faith. Calvin emphasizes that spiritual gifts (presumably including the greatest possible blessing of deification in the following verse) cannot be given until we are first 'led to know God... [by] the inward call, effected by the hidden power of the Spirit when God not only sounds in our ears by the voice of man, but draws inwardly out hearts of himself by his own Spirit' (Calvin 1963: 329). One could interpret Calvin as restricting the work of the Holy Spirit to epistemology and employing theosis as a more ontological or holistic transformation. 
This is clearly implied in Sung Park's argument that Calvin believed in 'a Spirit-bonded union by faith, which has a personal and dynamic dimension, but not ontological' (Park 2017: 2; cf. Niesel 1962: 126; Venema 2012: 88). It is on this basis that Park, not only demarcates indwelling and theōsis, but rejects the idea that theosis or deification, as an ontological union, is truly found in Calvin's theology. This demarcation may seem promising but, unfortunately, Park's separation of epistemology from ontology in Calvin's thought is hard to sustain.

Although Calvin certainly emphasizes the Holy Spirit's role as an inner teacher, this is to have a holistic effect on the human individual (Calvin 1960: 552). If we return to his commentary on 2 Peter 1:3, Calvin summarizes his discussion of the indwelling of the Holy Spirit in this way: 'the effect of the calling in the elect is to restore to them the glorious image of God, and to renew them in holiness and righteousness' (Calvin 1963: 330). This is important because in his commentary on deification in verse 4, Calvin summarizes the concept of deification with almost the exact same language. Calvin writes,

But we, disregarding empty speculations, ought to be satisfied with this one thing - that the image of God in holiness and righteousness is restored to us for this end, that we may at length be partakers of eternal life and glory as far as it will be necessary for our complete felicity (Calvin 1963: 330).

Similarly, in the Institutes, Calvin expands his theology of the imago Dei by referring to the image as 'participation in God' (Calvin 1960: 256).

If we read Calvin's commentary on verses three and four together, it is clear that the inner call of the Holy Spirit is the means by which, not only knowledge and faith are given that allow for deification subsequently to occur through a separate process, but more directly the Spirit's indwelling effects deification in the human being (in so far as we follow Calvin's definition of deification as the restoration of the image of God as holiness and righteousness). Moreover, limiting the work of the Holy Spirit to epistemology neglects important aspects of the Scriptural witness regarding the role of the Spirit in bringing about the resurrection, the giving of gifts for good practice and ethical transformation, and the role of Spirit in the church and sacraments. It seems then that in Calvin's theology, any contrast between, on the one hand, the indwelling of the Spirit and epistemological transformation and, on the other hand, of deification with ontological participation is only a difference of emphasis, and not a clear-cut demarcation between indwelling and theōsis. 


\section{Demarcation 5: A Mereological Distinction}

The mereological distinction between theossis and the indwelling of the Spirit implies that the latter is part of a larger process of redemption, which may be referred to in its entirety as a theossis or deification. When we consider all the various components of salvation together, we are not merely left with a collection or list of discrete divine activities, but with a new whole or real salvific phenomena that is more than the mere collection of previous divine activities. This whole is what is referred to as theōsis or deification.

Something like this view is assumed by some of the main contemporary scholars who argue that the Reformed tradition affirms and employs the concept of deification. Strobel's examination of Edwards, for example, repeatedly states that 'theosis speaks of the broadest features of soteriology, and is not, therefore, a certain construction of justification, sanctification, or glorification... [theosis is] a foundation doctrine ordering (at least) soteriology in its entirety' (Strobel 2016: 373, 389). However, he unhelpfully offers an almost identical claim regarding the 'sending of the Spirit [which] brings about regeneration, justification, sanctification, and ultimately glorification'. (Strobel 2016: 373). This demarcation is clearer within the secondary scholarship on Calvin, which presents Calvin's view of deification as a two-stage process.

The first step took place in the hypostatic union through the communication of divine properties to the whole single person of Jesus Christ. For example, this means that Christ's human righteousness is the quality of the righteousness of God (a divine property), rather than just a human righteousness which comes from God in origin (Slater 2005: 39). The argument is that in Calvin's theology, Christ's human nature is deified through its union with Christ's divine nature (Mosser 2002: 46; Calvin 1960: 2.13-14). The deification of the humanity of Christ is matched by the humanization of the divinity of Christ, more typically referred to as kenosis, the giving up of divine attributes, or the self-emptying of the divine nature. Just as the Son of God undergoes some form of kenosis in the incarnation, the human nature of Christ undergoes some form of theōsis (Zorgdrager 2014: 362). This parallelism fits within the emphasis of the 'wonderful exchange' within Calvin's broader soteriology. The decisive point is that whatever articulation or model is used to understand how the Son's divine properties are held together with Jesus' human nature dictates what properties the ordinary human believer may receive when united with Christ's human nature by the Holy Spirit. Since the incarnation is an essential first stage, most of the discussion in the debate around theosis has focused on Calvin's Christology rather than his pneumatology. The same may be said for the discussion of theossis in the soteriology of T. F. Torrance (Habets 2009: 49-92; Crisp 2020: 18-22). 
However, the communication of properties remains only the first part of theōsis on this Calvin-inspired model. It is important that (without ever losing the anchor of Christology) Christian soteriology does not imply that the incarnation is the only mechanism or divine-human relation in operation. Without an alternative divine-human relation in soteriology, we might imagine that all humanity (or the elect) receive the benefits of Christ by also becoming incarnate, being personally assumed by the Son so as to be one single hypostasis with God (and one another). ${ }^{5}$

Contrary to this, as Julie Canlis notes, 'Calvin's genius was to perceive that without a genuine role for the Holy Spirit, you cannot help but to have a fusion, or a divine overwhelming of some sort' (Canlis 2004: 172). Calvin employs the Holy Spirit within a second stage of theossis in order to resist a fusion or divine overwhelming. As Mosser writes,

The role of the Holy Spirit should not be forgotten as he also plays an important role [in deification]. It is the Spirit who 'breathes divine life into us' (Institutes 3.1.3)... In sum, the Holy Spirit is the 'bond by which Christ effectually unites us to himself' (Institutes 3.1.1; 3.1.3) (Mosser 2002: 47).

Calvin is clear that the union by which human beings are bound to Godthat union which may affect deification or stand as an alternative for deification-is not just by the physical flesh or humanity of the incarnate Mediator, but also by the Spirit: 'Christ communicates His righteousness only to those whom He joins to Himself by the bond of His Spirit' (Calvin 1961b: 160). Therefore, 'we infer that we are one with Christ; not because He transfuses his substance into us, but because by the power of His Spirit He communicates to us His life and all the blessings He has received from the Father' (Calvin 1963: 148).

In his refutation of Servetus, Calvin emphasizes that the restoration of the image whereby 'man is made to conform to God, not by inflowing of substance, but by the grace and power of the Spirit... who surely works in us without rendering us consubstantial with God' (Calvin 1960: 191-2). Similarly, in his writing against Osiander it becomes clear that the Spirit plays an important intermediary function in Calvin's theology which both unites us to Christ, but in virtue of this spiritual union prevents any stronger essential unity of natures (Calvin 1960: 730-731). Again, without a clear consensus on how theōsis and the indwelling of the Holy Spirit are to relate as soteriological concepts, it is almost impossible to tell if these quotations from tion where humanity is hypostatically assumed by the Son. For a discussion see, Flint 2011. 
Calvin indicate a rejection of theōsis (as equivalent to a union of substance or essence) and instead a teaching on the indwelling of the Holy Spirit, or merely emphasize the importance of the indwelling of the Holy Spirit as a part of the overarching hope for deification. As Partee writes, it is not that Reformed theology is contrary to any union or intimate relationship between divinity and humanity, but, "The question is rather whether deification is the proper description of the transformative union' (Partee 2008: 176).

The mereological demarcation, employed as a way to avoid the loss of the human into the divine, is seen in Calvin's response to Osiander and in his consideration of Plato. Calvin criticizes Osiander for failing to see that believers are united to the whole person of Christ 'by the secret power of the Spirit' which is the 'bond of unity' and not by an infusion of the divine essence (Calvin 1960: 730). It is unsurprising, therefore, that Calvin's revisions to the Institutes in 1559, where the refutation of Osiander is found, also includes an expansion and enriching of Calvin's depiction of the Holy Spirit as the vinculum or coniunctio of union (Garcia 2004: 187). Osiander's failure here is also the decisive point of Plato's ignorance according to Calvin.

Whilst Calvin described the pagan version of deification, whereby exalted kings or military heroes are deified as a result of their earthly status or achievements, as invented deification (Calvin 1851: 306) and 'false deification' (Calvin 1960: 392), Calvin also commends Plato as a pagan philosopher who 'recognized man's highest good as union with God' (Calvin 1960: 988). Wherein then is Plato's error? Calvin writes that it is that Plato 'has learned nothing of the sacred bond of that union' (Calvin 1960: 988). Mosser writes that the sacred bond to which Calvin refers here is Christ himself [the hypostatic union], but surely the language of a 'sacred bond' is more congruent with Calvin's vocabulary for the Holy Spirit. Of course, Plato knew of neither incarnation nor indwelling, but in this passage, it is Plato's ignorance specifically of the indwelling of the Holy Spirit that remains the main problem with the pagan view of deification. This point should in no way undermine the importance that the incarnation had in soteriology for Calvin since the indwelling of the Holy Spirit unites us to Christ. However, Calvin's comment should underline for us the importance of the indwelling of the Holy Spirit, as a distinct concept, for Reformed notions of deification. Without the indwelling of the Holy Spirit at the forefront deification becomes problematic to Calvin, but that is not to say that indwelling and theosis are synonymous. Likewise, incarnation is a necessary component of deification, but this is not to say that these two divine acts are identical. ${ }^{6}$ This mer- 
eological demarcation implies that the indwelling of the Spirit is a necessary part, but insufficient description, of 'the end of the gospel', which is 'to render us eventually conformable to God, and, if we may so speak, to deify us' (Calvin 1963: 330).

There are a number of other explanatory advances to this method of demarcation. First, this demarcation also provides some explanation for the 'lack of dogmatic precision' in recent discussions of theōsis in the Reformed tradition, as resulting from 'the summative quality of deification: it brings together all that the Father has granted us through Christ and in the Spirit' (Keating 2015: 281). That is, this mereological demarcation tells us relatively little about the content, criteria, or mechanism for theosis. As was intended by this search for a demarcation, this account focuses on the relationship between various soteriological concepts and doctrines; it does not heavily prescribe the content of these doctrines. Second, if theosis is the summation of any one soteriological schema, it is unsurprising that we may find substantial differences between how different traditions employ the term. As was seen in relation to Demarcation 4, the more fruitful discussion may be to parse out different expressions or accounts of theossis within Christian theology, rather than argue that the concept is either wholly present or wholly absent within the various traditions of Christian theology.

\section{Conclusion}

The main argument of this paper has been to emphasize the present lack and urgent need for a clear demarcation between the indwelling of the Holy Spirit and the idea of theossis in Reformed theology. Progress in recent debates regarding the potential presence of theosis within the Reformed tradition, or the unique contribute of Reformed thought to this doctrine, can only be made once the relations between these teachings is better understood. After surveying various proposals, I have concluded that the most helpful way to distinguish between indwelling and deification in Reformed theology is what I have termed The Mereological Demarcation; namely, to view the indwelling of the Holy Spirit as a part of an overarching vision of soteriology, which in its completion may be called deification.

It is clear from the research displayed in this article that across the Reformed tradition, wherever union with God and the transformation of the human person are in focus, the indwelling of the Holy Spirit is never far from view. What we may have discovered, therefore, is that the indwelling of the Holy Spirit is a particularly Reformed emphasis upon the ecumenical concept of deification (although the same emphasis is found in Didymus the

ways that the Triune God relates to humanity. For more on this, see Leidenhag and Mullins 2018. 
Blind in the fourth century; Russell 2012: 162). This employment of the indwelling of the Holy Spirit may function as the Reformers alternative, not to theossis, but to the Eastern distinction between the essence/energies of God (although, if not carefully worked out, this comparison does invite the traditional criticism of a subordination of the Spirit in Western thought). The question remains if 'such a conceptual stretching [is] legitimate, or should deification be defined more restrictively?' (Gavrilyuk 2009: 651). Although this question lies beyond the scope of this paper to answer fully, it seems that replacing or reducing the concept of deification to be synonymous with the indwelling of the Holy Spirit would be illegitimate; a doctrine by any other name simply does not smell as sweet. However, having clearly demarcated these concepts, then using the indwelling of the Spirit within an overall vision of theosis seems both a legitimate and theologically beneficial articulation of the Christian hope.

\section{Bibliography}

Billings JT (2005) United to God through Christ: Assessing Calvin on the Question of Deification. Harvard Theological Review 98(3): 315-34.

. (2007a) Calvin, Participation and the Gift: The Activity of Believers in Union with Christ. Oxford: Oxford University Press.

. (2007b) John Calvin: United to God through Christ. In Christensen

MJ and Wittung JA (eds) Partakers of the Divine Nature: The History and Development of Deification in the Christian Traditions. Grand Rapids, MI: Baker, pp. 200-218.

Caldwell III RW (2006), Communion in the Spirit: The Holy Spirit as the Bond of Union in the Theology of Jonathan Edwards. Studies in Evangelical History and Theology. Carlisle, UK: Paternoster.

Calvin J (1851) Commentary on the Book of the Prophet Isaiah. Pringle W (trans). Edinburgh: Calvin Translation Society.

. (1948) Commentaries on the Catholic Epistles. Owen J (trans). Grand Rapids, MI: Eerdmans.

. (1960) Institutes on the Christian Religion. McNeill JT (ed) Battles FL (trans). Philadelphia, PA: Westminster.

. (1961) The Gospel According to St John 11-12 and the First Epistle of John.

Parker THL (trans). Grand Rapids: MI: Eerdmans.

. (1961b) The Epistles of Paul the Apostle to the Romans and to the Thessalonians. Makenzie R (trans). In Torrance DW and Torrance TF (eds) Calvin's Commentaries. Edinburgh: Oliver and Boyd.

. (1963) The Epistle of Paul the Apostle to the Hebrews and The First and Second Epistles of St Peter. Johnston WB (trans). Grand Rapids, MI: Eerdmans. 
. (2008) Institutes of the Christian Religion. Beveridge H (trans). Peabody, MA: Hendrickson Publishers.

Canlis J (2004) Calvin and Osiander and Participation in God. International Journal of Systematic Theology 6(2): 169-184.

. (2010) Calvin's Ladder: A Spiritual Theology of Ascent and Ascension. Cambridge, MI: Wm. B. Eerdmans.

Clagorn G (1989) Introduction to Jonathan Edwards', 'Unpublished Letter on Assurance and Participation in the Divine Nature'. In Ramsey P (ed) Ethical Writings: The Works of Jonathan Edwards, volume 8. New Haven: Yale University Press.

Crisp O (2010) Jonathan Edwards's Ontology: a critique of Sang Hyun Lee's dispositional account of Edwardsian metaphysics, Religious Studies 46: 1-20.

. (2012) Jonathan Edwards on God and Creation. Oxford: Oxford University Press.

. (2014) Jonathan Edwards on the Trinity, Jonathan Edwards Studies 4: 21-41.

. (2020) T.F. Torrance on Theosis and Universal Salvation, Scottish Journal of Theology (forthcoming).

Danaher Jr WJ (2004) The Trinitarian Ethics of Jonathan Edwards. Westminster John Knox Press.

De Kroon M (2001) The Honour of God and Human Salvation: Calvin's Theology According to His Institutes. Vriend J and Bierma LD (trans). New York/ Edinburgh: T\&T Clark.

Edwards J (1959) Religious Affections. In Smith JE (ed) The Works of Jonathan Edwards volume 2. New Haven: Yale University Press.

(1995) A Divine and Supernatural Light, Immediately Imparted to the Soul by the Spirit of God, Shown to be Both a Scripture and Rational Doctrine. In Smith JE, Stout HS and Minkema KP (eds) A Jonathan Edwards Reader. New Haven/London: Yale University Press.

. (1989) Concerning the End for Which God Created the World. In Ramsey P (ed)The Works of Jonathan Edwards: Ethical Writings volume 8. New Haven: Yale University Press.

. (1994) The Works of Jonathan Edwards, volume 13: The Miscellanies: A500. Stout HS (ed). New Haven: Yale University Press.

. (2001) Striving after Perfection. In Lesser MX (ed) Works of Jonathan Edwards volume 19: Sermons and Discourses, 1734-1738. New Haven: Yale University Press.

Finlan S and Kharlamov V (2006) Introduction. In Finlan S and Kharlamov V (eds) Theosis: Deification in Christian Theology. Cambridge, UK: James Clarke, pp.1-12. 
Flint TP (2011) Molinism and Incarnation. In Perszyk K (ed) Molinism: The Contemporary Debate. Oxford: Oxford University Press, pp.187-208.

Garcia MA (2004) Life in Christ: The Function of Union with Christ in the UnioDuplex Gratia Structure of Calvin's Soteriology with Special Reference to the Relationship of Justification and Sanctification in Sixteenth-Century Context. PhD Thesis. University of Edinburgh, U.K.

Gavrilyuk PL (2009) The Retrieval of Deification: How a Once-Despised Archaism Became an Ecumenical Desideratum. Modern Theology 25(4): 647-659.

Hallonsten G (2007) Theōsis in Recent Research. In Christensen MJ and Wittung JA (eds) Partakers of the Divine Nature: The History and Development of Deification in the Christian Traditions. Grand Rapids, MI: Baker, pp 28193.

Holmes S (2000) God of Grace and God of Glory: An Account of the Theology of Jonathan Edwards. Grand Rapids, MI: Eerdmans.

. (2003) Does Jonathan Edwards use a Dispositional Ontology? A Response to Sang Hyun Lee. In P Helm and O Crisp (eds) Jonathan Edwards: Philosophical Theology. Aldershot: Ashgate, pp. 99-114.

Habets M (2006) Reforming Theōsis. In Finlan S and Kharlamov V (eds) Theōsis: Deification in Christian Theology. Cambridge: James Clarke, pp. 146-67.

. (2009) Theōsis in the Theology of Thomas Torrance. Ashgate New Critical Thinking in Religion, Theology, and Biblical Studies Series. Farnham, UK: Ashgate.

Lee S-H (2000) The Philosophical Theology of Jonathan Edwards. Expanded edition. Princeton. N.J.: Princeton University Press.

. (2010) Calvin on Deification: A Reply to Carl Mosser and Jonathan Slater. Scottish Journal of Theology 63(3): 272-84.

Leidenhag J, and Mullins RT (2018) Flourishing in the Spirit: Distinguishing Incarnation and Indwelling for Theological Anthropology. In Crisp $\mathrm{O}$ and Sanders F (eds) The Christian Doctrine of Humanity: Explorations in Constructive Dogmatics. Grand Rapids, MI: Zondervan, pp. 182-99.

Long DS (2010) Christian Ethics: A Very Short Introduction. Oxford: Oxford University Press.

Louth A (2007) The Place of Theossis in Orthodox Theology. In Christensen MJ and Wittung JA (eds) Partakers of the Divine Nature: The History and Development of Deification in the Christian Traditions. Grand Rapids, MI: Baker, pp. 32-44.

Keating DA (2015) Typologies of Deification. International Journal of Systematic Theology 17(3): 267-283.

Kärkkäinen V-M (2004) One with God: Salvation as Deification and Justification. Collegeville, PA: Liturgical Press. 
McClelland J (1973) Sailing to Byzantium. In Meyendorff J and McClelland J (eds) The New Man: An Orthodox and Reformed Dialogue. New Brunswick: Agora Books, pp. 10-25.

McClymond M (2004) Salvation as Divinization: Jonathan Edwards, Gregory Palamas and the Theological Uses of Neoplatonism. In Crisp $\mathrm{O}$ and Helm P (ed) Jonathan Edwards: Philosophical Theologian. Aldershot, UK: Ashgate, pp. 139-60.

McCormack B (2010) Union with Christ in Calvin's Theology: Ground for a Divinization Theory? In Hall DW (ed) Tributes to John Calvin. Phillipsburg, N.J.: Presbyterian \& Reformed Publishing, pp. 504-529.

Mosser C (2002) The Greatest Possible Blessing: Calvin and Deification. Scottish Journal of Theology 55(1): 36-57.

(2014) An Exotic Flower? Calvin and the patristic doctrine of deification. In Parsons M (ed) Reformation Faith: Exegesis and Theology in the Protestant Reformations. Milton Keynes: Paternoster, pp. 38-56.

- (2015) Deification: A Truly Ecumenical Concept. Perspectives (July/August): 8-14.

Murphy G (2008) Reformed Theōsis? Theology Today 65(*): 191-212.

Niesel C (1962) Reformed Symbolics. D. Lewis (trans). Edinburgh: Oliver \& Boyd.

Norris FW (1996) Deification: Consensual and Cogent. Scottish Journal of Theology 49(4): 411-428.

Ollerton AJ (2011) Quasi Deificari: Deification in the theology of John Calvin. Westminster Theological Journal 73(*): 237-254.

Park SW (2017) The question of deification in the theology of John Calvin. Verbum et Ecclesia 38(1): 1-5.

Partee C (2008) The Theology of John Calvin. Louisville: Westminster John Knox Press.

Russell N (2004) The Doctrine of Deification in the Greek Patristic Tradition. Oxford: Oxford University Press.

Russell N (2012) Why does Theōsis Fascinate Western Christians? Sobornost $34(*): 5-15$.

Salladin J (2017) Essence and fullness: Evaluating the creator-creature distinction in Jonathan Edwards. Scottish Journal of Theology 70(4): 427-44.

Slater J (2005) Salvation as Participation in the Humanity of the Mediator in Calvin's Institutes of the Christian Religion: A Reply to Carl Mosser. Scottish Journal of Theology 58(1): 39-58.

Strobel K (2012a) Jonathan Edwards's Theology: A Reinterpretation. London: Bloomsbury/T\&T Clark.

- (2012b) Jonathan Edwards and the Polemics of Theōsis. Harvard Theological Review 105(3): 259-79.

. (2016) Jonathan Edwards's Reformed Doctrine of Theosis. Harvard Theological Review 109(3): 371-399. 
Torrance TF (1975) Theology in Reconstruction. Grand Rapids: Eerdmans. . (1989) The Soul and Person in Theological Perspective. In Sutherland SA and Roberts TA (eds) Religion, Reason and the Self: Essays in Honour of Hywel D. Lewis. Cardiff: University of Wales Press, pp. 103-18.

Venema CP (2007) Accepted and Renewed in Christ: The 'Twofold Grace of God' and the interpretation of Calvin's theology. Göttingen: Vandenhoeck \& Ruprecht.

Williams AN (1999) The Ground of Union: Deification in Aquinas and Palamas. New York and Oxford: Oxford University Press.

Williams R (1983) Deification. In Wakefield GS (ed) A Dictionary of Christian Spirituality. London: SCM Press.

Wendel F (1963) Calvin: The Origins and Development of His Religious Thought. New York: Harper \& Row.

Zorgdrager HE (2014) On the Fullness of Salvation: Tracking theōsis in Reformed theology. Journal of Reformed Theology 8(*): 357-381. 